\title{
The Influence of Talent Management on Performance of Employee in Public Sector Institutions of the UAE
}

\author{
Mahmoud Kaleem ${ }^{1}$ \\ ${ }^{1}$ Department of Public Relations and Advertising, City University College of Ajman, Ajman, UAE \\ Correspondence: Mahmoud Kaleem, Department of Public Relations and Advertising, City University College \\ of Ajman, Ajman, UAE. Tel: 97-15-0717-6774. E-mail: aburaedm1@gmail.com
}

Received: May 14, 2019 Accepted: June 16, 2019 Online Published: October 31, 2019

doi:10.5539/par.v8n2p8

URL: http://dx.doi.org/10.5539/par.v8n2p8

\begin{abstract}
Talent management is the discipline of using strategic human capital planning to improve the value of business and induce it for enterprises organizations to achieve their objectives. It refers the organization's ability to recruit, reward, organize, and retain most talented employees available in job market. In the modern era it has become very important and necessary skill for the workforce to acquire the one's good skills, cognitive abilities, knowledge, and potential to do well for the business strategy to function more appropriately. Talent management is the training strategy for the employees that are set within an organization platform. The organizations where the most productive employees can pick and choose the tasks according to their will and capability are found more beneficial and productive for the organizations. In the adverse economic circumstances, companies are trying to cut their expenses so the talent management system is the means to optimize the performance of each employee.

The basic aim of this study is to explore the influences of talent management strategiesto determine the employees' performancein selected public sector organizations of UAE. The core function of this study examines, how talent management practicescan enhance the employee's satisfaction and productive performance, instead of being process of hiring, reinforcing and evaluating the aptitude. Efforts have been made to retain, attract, develop, and reward employees. This study puts forward valid descriptive hypothesesdata, based on a survey collected through the employees of the nationalorganizationsofthe UAE. A pre-plannedsurvey has been used on a sample of more than two hundred (200) employees working in different organizations for the collection of primary data. This research work is steered by the following explorative questions:At what level does talent acquisition affectsthe performance of employee, at what level of extensive, does the impact of talent development affects the employee performance, to what extent does the talent retention enhance the performance of the employees, to what extent does the talent management enhance the performance of the employees.

The stratified methodology for data collection is adoptedfor the selection the sample size of 200plaintiffs. A well-organized structuredand to the pointquestionnaire is utilized for the collection of raw data. The collected raw data is analyzed for both of inferential (correlation analysis) and descriptive (percentages and frequencies) statistics. Tables and figures are used to represent the data. The finding indicates that talent management practices have direct impact on employee's motivation, creativity, satisfaction and employee competency. The study recommends that there should be healthy and stress free working environment, career progression opportunity, regular training, welcome employees' innovative idea and transparent proper promotion policy for the management of talent in the organization.
\end{abstract}

Keywords: talent management, employee performance, training and development, employee retention, career development

\section{Introduction}

The idea of talent management emerged with evolution of corporate human resource and training, the concept of talent management originated in 1990, when the responsibilities of human resources were mainly shifted from being routine administration processing to more complex configuration and machine based planning duties. At that time decision makers exclusively relied on HR department for employee management and training in the competent evaluation of modern industry and business sectors. During this probationary era public sector organization had realized that human resources management had a great role in recruiting and training of 
workforce and make them fit for competing environment in order to attain maximum capabilities of the employees. The human resource departments played an important role in developing the good packages of compensation which includes peripheral benefits, bonuses, appreciations, and leaves and health benefits. These benefits are serving as central point of communication related with the health and happiness of employees.

Talent management deals with the manpower or workforce thatcompriseson the skills and knowledge of the workers. In the recentstudies, it has been noted that talent management has become global challenge of confrontation for the organizations. Due to the lack of talent exercised through the world competing for the same pool to keep the talent market of the intellect that their life will continue to grow in words and operations and profitability. All good organization that technology integration and reasons, but people cannot easily reproduce takes a lot of time to develop the head of football and is considered as the key to adapting and managing organizational requirements. By allocating the resources and technologies, it alters the ways on which firms are organized and extract the optimal performance from the employees. Apart from that, progress of talent management is very important in the developing and discovering new talented employees in the market of workforce. Advances in talent management system such as digital HR, is useful weapon for HR leaders to implement global recruiting strategies where they residence. The talent management is the proactive approach to create the better employment opportunity, internal mobility and quality of employing.

Talent management emphases on procurement of talents, integration and adaptation of talent, development, reward, participation and training. Having skilled employees implies that organizations must know how to identify, manage, develop keep and get the best out of their right people, and strategically implement talent and ensure that there are enough talent channels to support the organizationstrategic goals. Talent management focuses on cultivating and retaining qualified talent. It rises the better opportunities for workforces at all levels in the organizations. However, it is not enough to improve performance an organization, true success comes from the hearts and thoughts of individuals in the organization. Talent management strategies help employees to engage both by their heart and mind and become loyal to their work with complete enthusiasm. Because the feeling and emotions drive individual behavior and more related to human mind and heart. So talent management enables the organizations to make their employees feel comfortable and fit in their job requirements.As a result they play a positive part for the development and progress of organization. Researchers claim that talent management enables organizations to operate efficiently in their operationsDepartments andtalent is very important asset. This kind of human capital and talent can provide competitive advantage to organizations in the public sector organizations. With reference to this context talent development strategies have a great impact on finding, acquiring, and maintaining the talented employees and make possible steps to use them for the wellbeing of the organizations in the competitive environment.The need of the hour is to align all the departments of the organization in order to attain sustainable advantages and competitive performance according to the functional capabilities of the employees.

This study measures the influences of talent management based on theperformances of employees in public sector organizations of UAE. Many researchers investigate the correspondence between talent management exercisesand organizational performances. Contrary to that, this research investigates the correlation of talent management policies and employee performance. The survey is limited to UAE public sector organizations because it has the fastest growth of the economy. Given the global perspective, it is concluded that the public sector will become the main sector of the economy in terms of growth contribution.

\subsection{Problem Statement}

Several studies have revealed that talent management is a tool of employee's retention, motivation and development. Rust and Koketso study on the perceived challenges to talent management has been marred in many instances by poor recruitment practices; the inability to attract and retain suitably qualified staff; and the lack of performance management systems. Their findings indicate the prediction that the employee engagement and their performance are vital for both of talent management and organization culture. The studies of Wambui (2002) and Lyria (2013) revealed that there is a positive strong correlation between performance of employee and talent management.To remain competitive, the organization needs to be able to effectively function in the absence of selected individuals. This can only be done if the talent management measures and retention strategies are implemented. The implication is done if every employee ultimately plays his overall role for organization performance. However, the previous studies are not encompassing the impact of talent management strategies in the context of UAE. Therefore, this study tries to reveal the effects of the talent management by providing the experimental data on the employee performance in the United Arab Emirates, and also endeavors to complete the available literature. 


\subsection{Objective}

The impartial of the study is to explore present scenario of the talent management in the public sector organizations of UAE. The relationship of four dimensions of talent managements that is talent acquisition, development, retention and development with employee's performance is analyzed in public sector organizations of UAE. The study will help theorganizations to improve the degree of employee retention, performance, satisfaction, enthusiasm and loyalty to their workplace.

\subsection{Research Questions}

- To what extent does talent acquisitionaffect employee performance?

- To what extent the impact of talent developmentaffect the performance of employee?

- To what extent does the talent retention enhance the performance of the employees?

- To what extent does the talent management enhance the performance of employees?

\subsection{Talent Management}

The term talent management refers the process that is involved in strategic human capital planning to improve the value of business and induce it for companies and organizations to achieve their goals. It is the organization's ability to retain, recruit, reward, organize, and deploy high potential talented individuals for future leadership positions available in organization. The recent studies of HRM indicatethat employee retention attains the major focus as a noteworthy part of the talent management program. As it includes in performance management, HR development, training, qualified workforce supply and demand, overall strategic planning of talent management, career development. Nevertheless, the complete premeditated objective of talent management is develop and sustains leader for the success of organization.

\subsection{Performance of Employee}

The judgment procedure to determine the performance of the employee is refer toworking capability of an employee that what can he does or does not.Employee performance is commonly determine through the task or jobs assign to him. The performance of task may includeexistence at work, quality of work,quantity of output,and timelinessof output, cooperativeness and behavioral aspects.

\subsection{Effect of Talent Acquisition on Employee Performance}

The process of talent acquisition is the process to acquire, estimate and recruitbest candidates for the roles to achieve organization goals and the need to carry out the projects. The acquisition process will have direct impact on employee performance in their job roles. For best employee performance, right man for the right job is required which can only be ensured by implementing best talent acquisition strategies. It will ensure that the organization will quickly and fully benefit from employee's potential hence improving employee's own performance. Talent Acquisition is one of the six key human capital processes defined by Talent Development Reporting Program (TDRP) and includes:

- Recruiting

- Talent assessment

- Talent selection

- Onboarding

The officials of Global Human Resources and Development would have to do more instead of attracting of talent. The need of the hour is to take necessary steps like outreach networking, employment branding, and relationship building for the potential candidates in addition with enhance the talent pool for qualified and skilled labor according to the requirements of the organizations needful arrangement.

\subsection{Effect of Talent Development on Employee Performance}

Training is a planned learning process of an activity or set of activity which is used to upgrade skill, behavior or knowledge to achieve the best performance.Development is the learning process of experiences that is used to enhance the skill and task attitude of individual through the results of his or her learning experience. The economic impact of talent acquisition and mobility shows the opportunities for cost reduction and improved corporate performance by talent development strategies. The performance based reward system by organization is the key element of the performance management that is used to ensure the addictiveness of and employee with his work activities and outcomes are corresponding with the objective of organization. Entailed specific activities and outcome of an employee is directly tied with the firm's strategy. As the performance based reward system for 
the employee having powerful incentives to perform creatively and diligently towards the objective goals of an organization. Performance management systems that are directly tied to an organization's reward system provide a powerful incentive for employees to work diligently and creatively toward achieving organizational objectives, not only employers but also employees are becoming more aware of the fact that there are some skills and characteristics which are essential to function properly in the workplace.

\subsection{Effect of Talent Retention on Employee Performance}

Talent retention is the organization's ability to retain its employees. Retention can be represented by a simple statistic. However, the retention of employees is a complete strategy as competition for talented employees is always severe. Efforts should be directed to those workers that are valuable and talented. The lack of satisfaction and commitment to the organization will result in the employee's quest for new opportunities. Do not always pay to play a big role in helping what is normally believed to be turnover.

As the every employee has right to know that what he is going to do and how can he improves his performance at his work place so, he can uplift his personal value and respect. Therefore, talent retention engaged employees through motivation and helps them to understand their value at organization. As the talent retention gives employee permanent feedbacks on their performances and acknowledge their solid stellar performance by encourage them to utilize their best potential for the better prospects of organization. Talent retention is also helpful to identify the performance shortfalls before these issues becomes a serious kind of problems and may lead high turnover rate regarding the performance of other employees. Development plans supports the performance of the employees and feedback should be accompanied by the coaching to establish the substantive working relationship between top management and employeeor coworkers. The investment on the employee's growth based on the ongoing performance boost the loyalty and retention. This keeps employee more connected with the organization for the long term growth of the organization and goodwill.

\subsection{Employee Performance and Effect of Talent Management}

Talent management involves identifying and development of all talents, particularly high potential talents for future tasks, projects or positions. The assimilated approach to talent management compriseson planning for workforce, talent recruitment, performance management,professional development, retention strategy andplanning of succession. This is important in any organization, as it helps development of the organization and its employees. Organizations with the development of workers can produce better results. The most critical policy of the organization includes: addressing with change intalent management guideline, preservation knowledge, performance management, development of leadership, creativity/Innovation participation, measurement of human capital succession planning, and management of the world's workforce.Companies all over the world have talent management as a top priority, so these kinds of activities are characterized by a comparatively high degree of complex strategies.

According to McKinsey's global procurement survey of more than 200 companies, organizations that use best talent management of the market staff are different from that of the ordinary organization. Three dimensions of talent include the ability of attracting talent itself, the talent dimensions relate to how employers see them and their desire to connect with them.

\section{Research Methodology}

This section consists ofthe methodology and discusses how the research was conducted and how the data was collected and analyzed. This section consists of the following subsections:designing of population and sampling data, research procedure, methods for data collection, research design, and finally, data analysis methods.

\subsection{Research Design}

The research design is a technique for the collection, measurement and analysis of data. This articleelucidates the structure of the research problem that implies a research plan to obtain realistic evidence about the relationship's framework, of an organization or configure the correlation between different variablesstudy. This research work is applied forimaginative research design, due to its purpose is to create aprecisedepiction of individuals, during different events or situations. A typical research design informs about things in which different circumstances will help to establish the current position of the studied population. This research workhas four sovereign variable.Talent Acquisition, Talent development; Talent management and Talent retention. The performance of the employee is the dependent variable.

\subsection{The Population}

The well-defined set or group of people or data, services or elements, groups of things that are being to 
investigate is known as population. The total elements of the collection about which we wish to make interface to obtain specific information is known as population. In this study the target population in the selected public sector organizations of UAE is 200 in number. Due to some logistic prospects it is easier to conduct research on smaller and simple population rather than whole group of population. The sample population is divided into three categories on the base of job title. This distributionisrevealed in the Table 1;

Table 1. Distribution of population

\begin{tabular}{ccc}
\hline Category & Population & Percentage \\
\hline Senior Level Management & 62 & $31 \%$ \\
Middle Level Management & 88 & $44 \%$ \\
Junior Level Management & 50 & $25 \%$ \\
Total & 200 & $100 \%$ \\
\hline
\end{tabular}

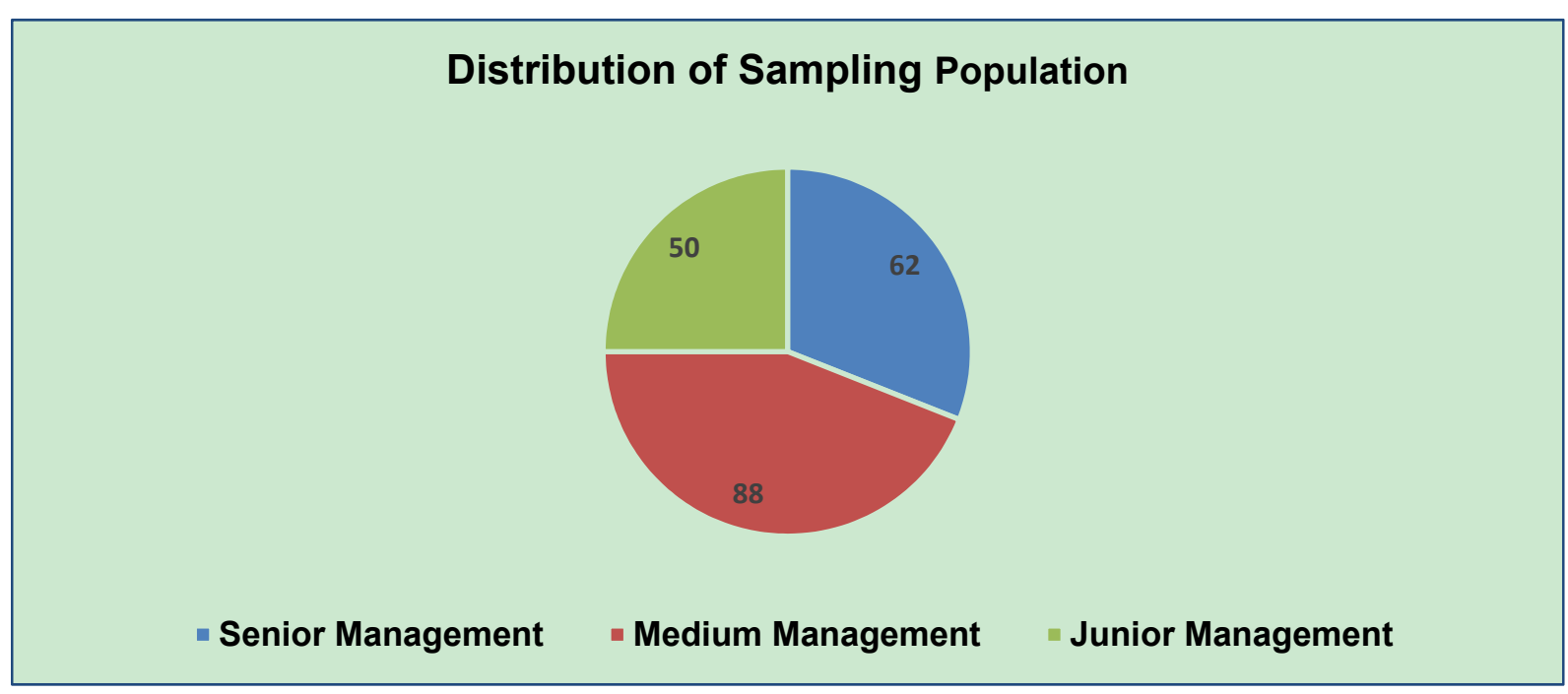

Figure 1. Distribution of sampling population

\subsection{Sample Size}

The sample size comprised of 200 employees.

\subsection{Sampling Design}

Sampling design is the selected population as the representative of whole population. A sampling frame is a set of elements or group of things that is selected by the researcher as a sample or targeted population. The sampling frame of this study was the list of all employees working in the head offices of selected public sector organizations of UAE provided by the HRM department of these organizations. The human capital or workforceis categorized into higher-ranker level, supervisor level and junior level management.

\subsection{Sampling Technique}

Proportional stratified random sample technique is used to ensure fair generalized representation for finding of general conclusions and outcomes. Stratified sampling provides an increase in statistical efficiency in a sample that provides sufficient data to analyze the different sub-populations and allows variety of researchmethodologies and techniquesare used atdissimilarlevels. Proportional stratified sampling technique is appliedas the population are in separate categories from already identified sample of population. The different layers of population is rated into some simple ratio by using data collection method. The primary data is collected through a questionnaire to obtain the desired results. The questionnaire is consisted on both type of open and closed questions depend upon the objectives of the research. 


\subsection{Data Collection Methods}

The primary data is collected through a questionnaire to obtain the desired results. The questionnaire is consisted on both type of open and closed questions depend upon the objectives of the research. The selected methodology is based on the assumption from where the data collected by means of a survey are easy to understand and are therefore considered valid. In addition, the use of the questionnaire makes it possible to better control the search process. The questionnaire consisted of two parts. The initialportion of the questionnaire included queries about commoninformationsrelated toparticipant relationship withthe firm. The $2^{\text {nd }}$ part dealt with talent management strategies and aspects of the employee performance. The surveyiswell-thought-structured onbase oflikescales of $1-5$ whereasstrongly agreed-1; agreed-2; Neutral-3; Disagreed-4; Strongly Disagreed -5 . Scale of like for measurement the attitude use in this study is shown in the. [Appendix-A].

The questionnaires were distributed to the employees through drop-and-pick method, and responses was given and collected after one week. In addition online Google form both in English and Arabic were used. There were more than 200 employees in which 156 were the respondents. The bestnoteworthy challenges faced by the researcher was getting the questionnaire fill by respective women participants.

\subsection{Data Analyzing Mechanism}

The data preparation was done before processing of responses, by complete editing, coding, cleaning of data collected through questionnaires. Quantitative method is used for analyzing the data. To ensure the effectiveness of data and minimization of error rate questionnaires was encoded according to each variable of the study and assure accuracy during analysis. Descriptive statistics is used for the quantitative analysis.

\section{Results and Discussions}

The results and findings of this study are discussed in this section. Initially descriptive characteristics of respondents are presented through demographic data, then descriptive statistics of talent acquisition, talent training, talent retention, and talent development strategies are highlighted. Inferential statistics presents the correlation. The 20.0 version is used of Statistical Package for Social Sciences (SPSS) to analyze the data. The outcome results are shown in the form of tables and figure to determine the measuring statistics of classified data.

\subsection{Demography Data}

Demography data of this research based study includes respondents classified on the base of their age, level of job, and how many years does the respondent is associated with particular organization, performance of the performance based rating of the respondent employee and official data collected from the relevant HR departmentsof the organizations.

\subsection{Gender of Respondent}

The basic purpose of this question was to find out the gender distribution of various respondents in selected public organizations of UAE. The results of the finding are indicated in the table 2 and figure given below. The falloutsshows that $52 \%$ of the respondent were men and $48 \%$ of the respondent are woman. It has been observed that male respondents are $4 \%$ more than female respondent.

Table 2. Gender of respondents

\begin{tabular}{ccc}
\hline MALE & 81 & $52 \%$ \\
\hline FEMALE & 75 & $48 \%$ \\
\hline
\end{tabular}




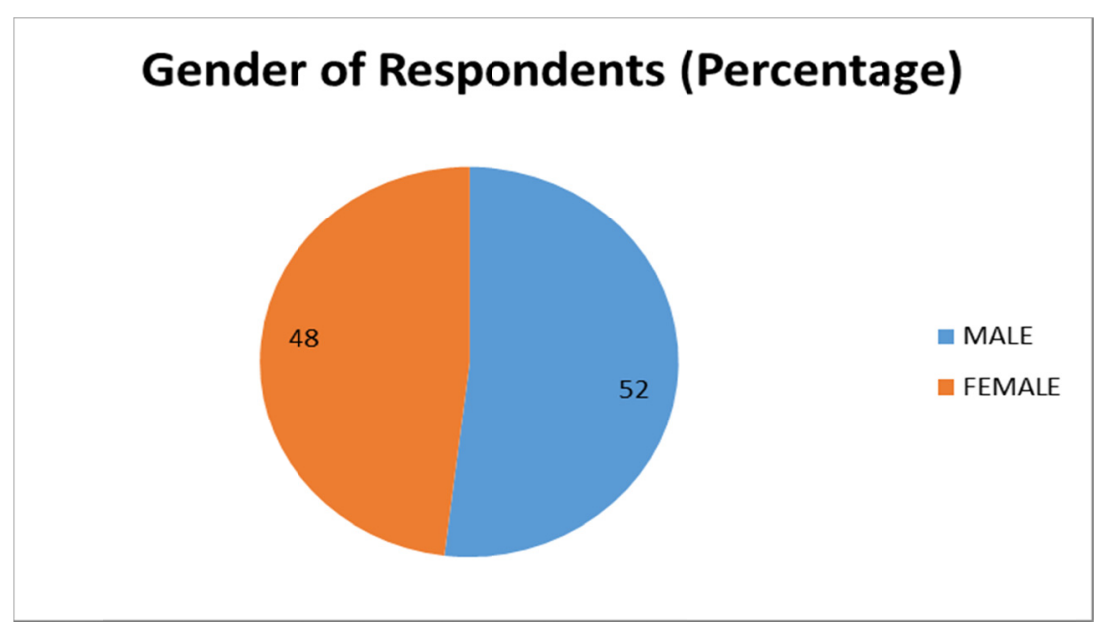

Figure 2. Gender of respondents

\subsection{Job Level of Respondents}

The particular question related to the job level of the respondent is sought out to determine the different level of jobs are performed by the selected people in thepublic organizationsare working. The outcomes results of the findings are illustrated in the table 3 while figure 3 shows the graphical representation. The derived results shows that $31 \%$ of the respondents were CEOs, $44 \%$ arethe managers of middle level, while $25 \%$ were the managers of junior level.

Table 3. Respondent job level

\begin{tabular}{ccc}
\hline Senior Management & 48 & $31 \%$ \\
\hline Middle Management & 69 & $44 \%$ \\
\hline Junior Management & 39 & $25 \%$ \\
\hline
\end{tabular}

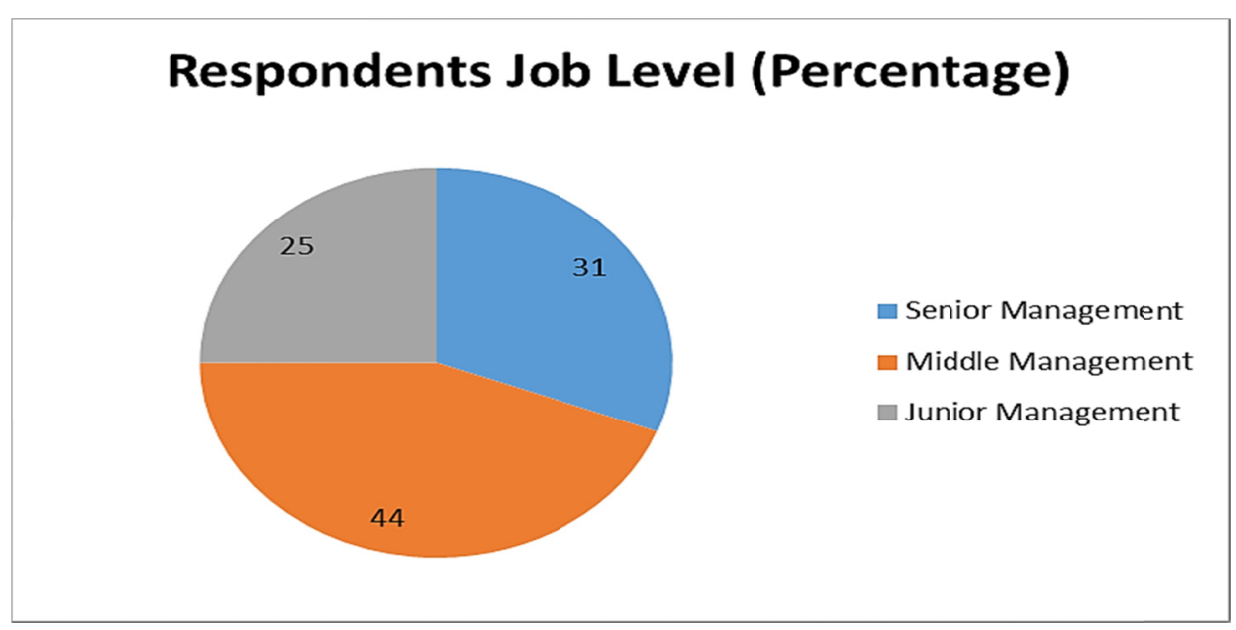

Figure 3. Respondent job level

\subsection{Numbers of Year Does Respondentare Working within Organizations}

This particular question asked to the respondent that how much number of years does he is working with the specific organization. The basic purpose of this question is sought out the specific reason for the respondent to stay with company or organization of UAE. The figure 4 shows the findings of this question, the results shows the following statistical information. There are $44 \%$ of numbers of respondents that had worked for 9years or 
more, in a particular organization. While $25 \%$ of the total population had 3-5 years working experience in the same organization. The $13 \%$ of the total population is working for $6-8$ years in the same organization, while there is $17 \%$ of the whole population just having 1-2 years working relation in a particular organization.

Table 4. Numbers of years of respondents (Percentage)

\begin{tabular}{ccc}
\hline 9 Years and Over & 69 & $44 \%$ \\
\hline 3-5 Years & 39 & $25 \%$ \\
6-8 Years & 21 & $13 \%$ \\
1-2 Years & 27 & $17 \%$ \\
\hline
\end{tabular}

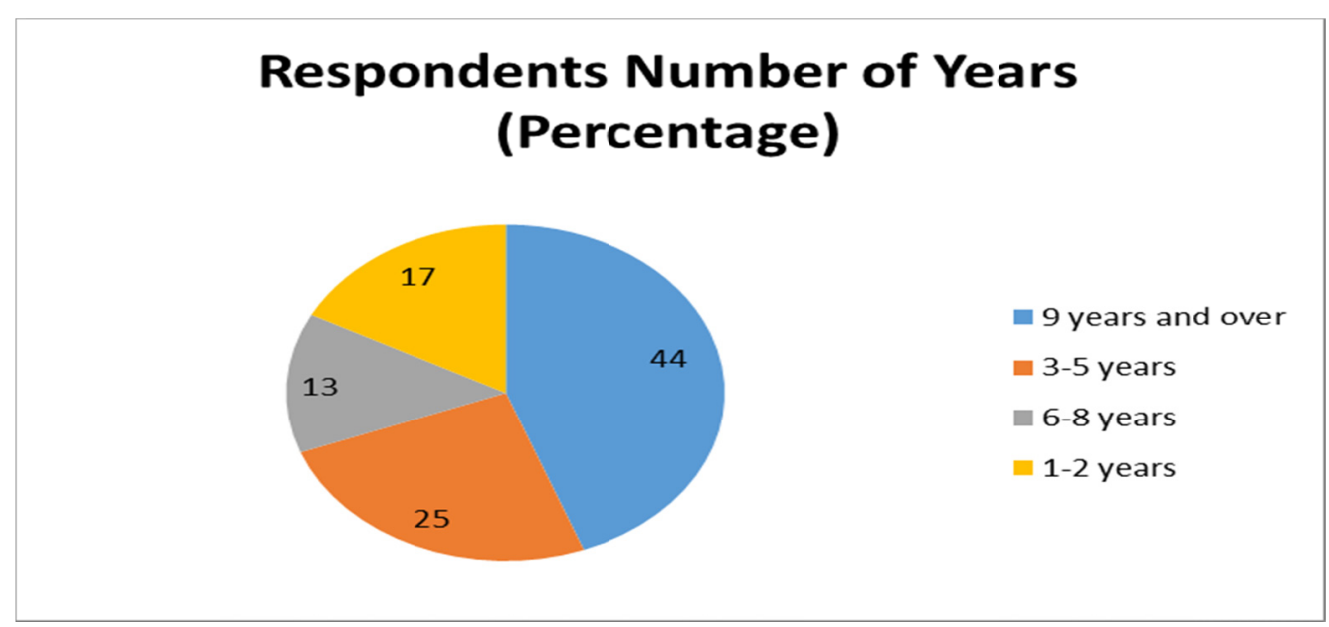

Figure 4. Respondent number of years

\subsection{Recitation Rating of the Respondents}

The question about the performance based rating is asked to determine the performance rating of an employee. The information collected by this question highlights the issues and factors that affects the performance of the respondents. The statistical analysis shows that the performance of $38 \%$ of respondents are excellent. While the performance of $50 \%$ respondents of total population is good, only $4 \%$ of the respondents have good performance rating. The remaining $8 \%$ of total population have an average performance rating so, they need to have improve their performance up to level of satisfactory.

Table 5. Respondents performance rating

\begin{tabular}{ccc}
\hline Excellent & 60 & $38 \%$ \\
\hline Very Good & 78 & $50 \%$ \\
\hline Good & 6 & $4 \%$ \\
\hline Room for Improvement & 12 & $8 \%$ \\
\hline Not to my satisfaction & 0 & 0 \\
\hline
\end{tabular}




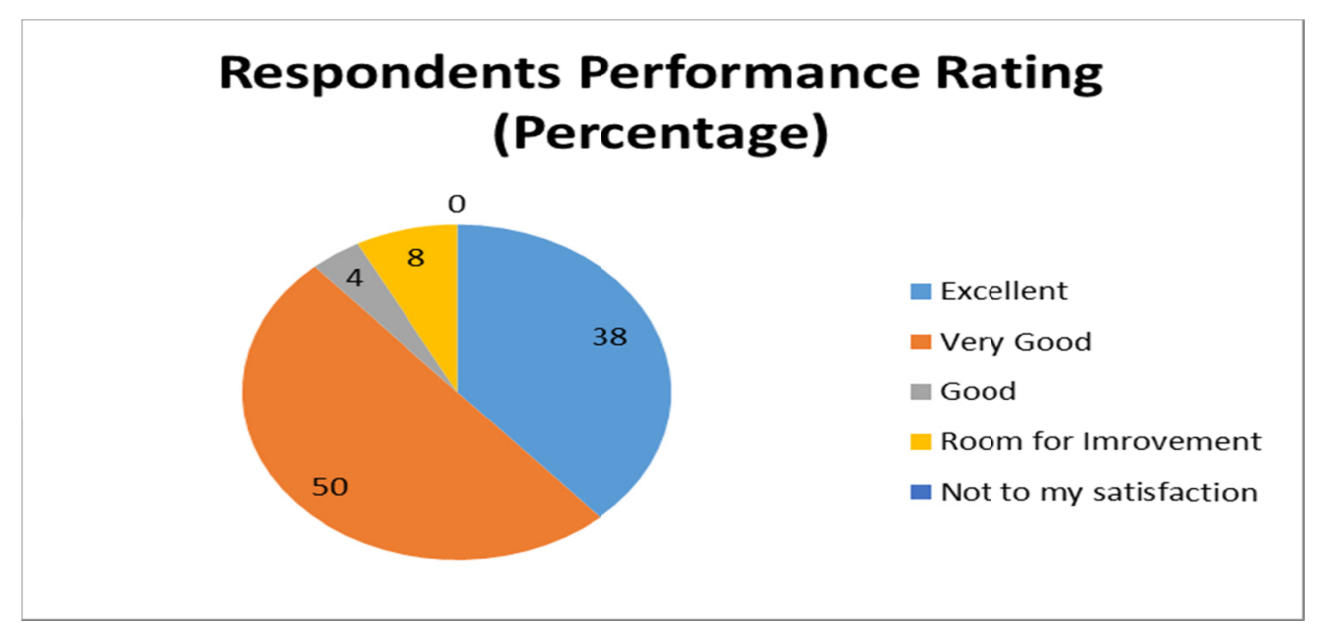

Figure 5. Respondent performance rating

\subsection{Significance of Human Resources}

This question was asked to determine either human resources department of the particular organization is working properly or not. In other words this question helps to determine the significance of the HRM department based on the opinion of the respondents. The end results shows that $75 \%$ of the total population agreed that HRM department is relevant to the organization and $25 \%$ felt that HRM department having not signification or not working relevantly. Figure 6 illustrate the end results of this particular question.

Table 6. Human resource relevance

\begin{tabular}{ccc}
\hline Yes & 117 & $75 \%$ \\
\hline No & 39 & $25 \%$ \\
\hline
\end{tabular}

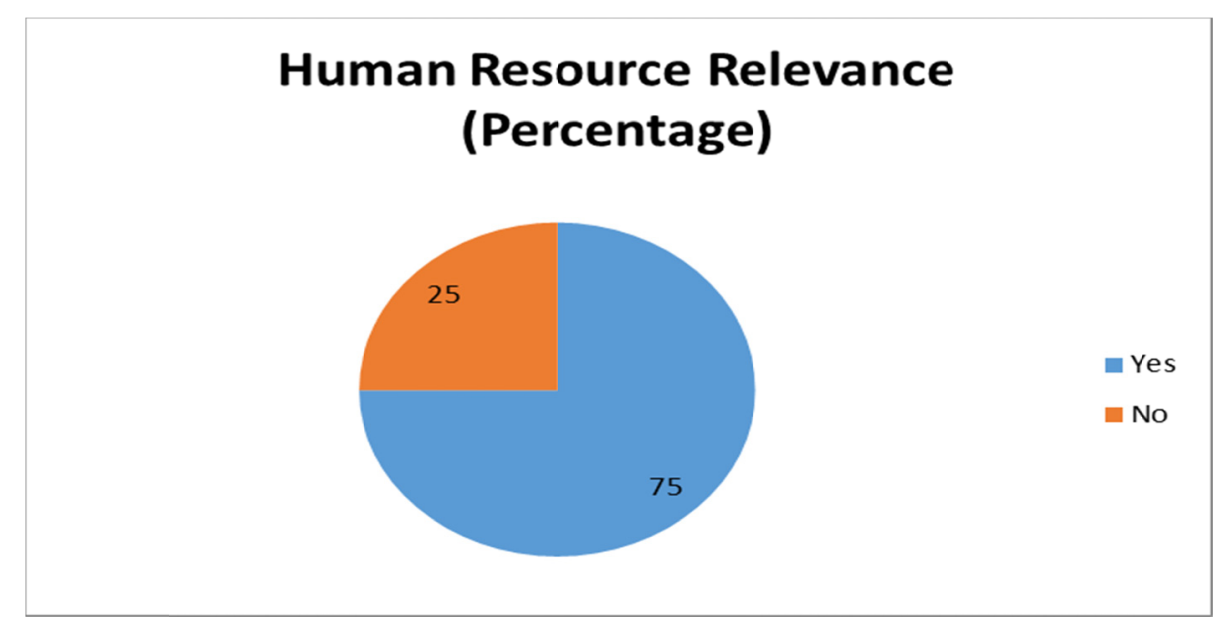

Figure 6. Human resource relevance

\subsection{Talent acquisition and Employees Performance}

This segment pursued to conclude the persuasion of the respondent on to what extents,does the talent acquisition affects the performance of the employees. The finding are shown in table 7.The participants of this questionnaire survey were asked to designate whether my organization has a fair and transparent talent acquisition policy and process. The result shows that $27 \%$ sturdily agree, $27 \%$ agree, $25 \%$ were impartial, $17 \%$ disagree while $4 \%$ were sturdily disagree. When asked whether my organization knows the value of running the cycle of talent 
acquisition timely, $13 \%$ sturdily agree, $38 \%$ agree, $23 \%$ were impartial, $21 \%$ disagree while $4 \%$ were sturdily disagree.On the question whether Talent acquisition process and timelines are shared with the candidates $8 \%$ sturdily agree, $46 \%$ agree, $17 \%$ were impartial, $19 \%$ disagree while $10 \%$ were sturdily disagree. When asked whether after acquiring talent the process of on boarding the employees is friendly and easy $10 \%$ sturdily agree, $44 \%$ agree, $25 \%$ were impartial, $17 \%$ disagree while $4 \%$ were sturdily disagree. When asked whether after acquiring talent the process of on boarding the employees is friendly and easy $10 \%$ sturdily agree, $44 \%$ agree, $25 \%$ were impartial, $17 \%$ disagree while $4 \%$ were sturdily disagree.

Table 7. Talent acquisition and employees performance

\begin{tabular}{|c|c|c|c|c|c|c|c|c|c|c|}
\hline \multirow[t]{2}{*}{ Talent Acquisition } & \multicolumn{2}{|c|}{ Sturdily Agree } & \multicolumn{2}{|c|}{ Agree } & \multicolumn{2}{|c|}{ Impartial } & \multicolumn{2}{|c|}{ Disagree } & \multicolumn{2}{|c|}{ SturdilyDisagree } \\
\hline & $\mathbf{F}$ & $\%$ & $\mathbf{F}$ & $\%$ & $\mathbf{F}$ & $\%$ & $\mathbf{F}$ & $\%$ & $\mathbf{F}$ & $\%$ \\
\hline $\begin{array}{l}\text { Q1 My organization has a fair and transparent talent acquisition } \\
\text { policy \& process. }\end{array}$ & 42 & 27 & 42 & 27 & 39 & 25 & 27 & 17 & 6 & 4 \\
\hline $\begin{array}{l}\text { Q2 My organization knows the value of running the cycle of } \\
\text { talent acquisition timely. }\end{array}$ & 21 & 13 & 60 & 38 & 36 & 23 & 33 & 21 & 6 & 4 \\
\hline $\begin{array}{l}\text { Q3 Talent acquisition process and timelines are shared with the } \\
\text { candidates. }\end{array}$ & 12 & 8 & 72 & 46 & 27 & 17 & 30 & 19 & 15 & 10 \\
\hline $\begin{array}{l}\text { Q4 After acquiring talent the process of onboarding the } \\
\text { employees is friendly and easy. }\end{array}$ & 15 & 10 & 69 & 44 & 39 & 25 & 27 & 17 & 6 & 4 \\
\hline
\end{tabular}

\subsection{Talent Development and Employees Performance}

This segment pursued to conclude the opinions of the respondent on to what extents talent development affects the concert of the employees. The finding are shown in the table 8.The participants of this questionnaire survey were asked to designate whether my organization facilitates employees to learn job related competencies. The results shows that $12 \%$ are sturdilyagree, $42 \%$ agree, $23 \%$, were impartial, $17 \%$ disagree while $10 \%$ were sturdily disagree.Respondents of the study were asked to indicate whether my organization offers systematic training to employee. The results shows that $15 \%$ are sturdilyagree, $42 \%$ agree, $25 \%$, were impartial, $8 \%$ disagree while $10 \%$ were sturdily disagree.On the question to respondent of the study were asked to indicate whether my organization improves the talent .The results shows that $17 \%$ are sturdilyagree, $33 \%$ agree, $31 \%$, were impartial, $12 \%$ disagree while $8 \%$ were sturdily disagree. On the question to respondent of the study were asked to indicate whether my organization implements staff development activities. The results shows that $12 \%$ are sturdilyagree, $42 \%$ agree, $29 \%$, were impartial, $12 \%$ disagree while $6 \%$ were sturdily disagree.

Table 8. Talent development and employees performance

\begin{tabular}{|c|c|c|c|c|c|c|c|c|c|c|}
\hline \multirow[t]{2}{*}{ Talent Development } & \multicolumn{2}{|c|}{ Sturdily Agree } & \multicolumn{2}{|c|}{ Agree } & \multicolumn{2}{|c|}{ Impartial } & \multicolumn{2}{|c|}{ Disagree } & \multicolumn{2}{|c|}{ Sturdily Disagree } \\
\hline & $\mathbf{F}$ & $\%$ & $\mathbf{F}$ & $\%$ & $\mathbf{F}$ & $\%$ & $\mathbf{F}$ & $\%$ & $\mathbf{F}$ & $\%$ \\
\hline $\begin{array}{l}\text { Q5 My organization facilitates employees to learn job related } \\
\text { competencies. }\end{array}$ & 18 & 12 & 66 & 42 & 36 & 23 & 21 & 13 & 15 & 10 \\
\hline Q6 My organization offers systematic trainings to employees. & 24 & 15 & 66 & 42 & 39 & 25 & 12 & 8 & 15 & 10 \\
\hline Q7 My organization improves talent. & 27 & 17 & 51 & 33 & 48 & 31 & 18 & 12 & 12 & 8 \\
\hline Q8 My organization implements staff development activities. & 18 & 12 & 66 & 42 & 45 & 29 & 18 & 12 & 9 & 6 \\
\hline
\end{tabular}

\subsection{Talent Retention and Performance of Employees}

This segment pursued to conclude the opinions of the respondents on to what extents talent retention affects the performance of the employees. The finding are shown in the table 9. The participants of this questionnaire survey were asked to designatewhether my organization has a mechanism to find talent within the organization. The results shows that $15 \%$ are sturdily agree, $35 \%$ agree, $29 \%$, were impartial, $15 \%$ disagree and only $6 \%$ were 
sturdily disagree.Respondents of the study were asked to indicate whether my organization evaluate and communicates job performance of employees. The results shows that $10 \%$ are sturdily agree, $44 \%$ agree, $23 \%$, were impartial, $17 \%$ disagree and only $6 \%$ were sturdily disagree.On the question to respondent of the study were asked to indicate whether performance appraisals have a positive impact on employee's performance. The results shows that $23 \%$ are sturdily agree, $40 \%$ agree, $10 \%$, were impartial, $17 \%$ disagree and only $10 \%$ were sturdily disagree.On the question to respondent of the study were asked to indicate whether my organization believes that all positions need talented employees. The results shows that $13 \%$ are sturdily agree, $33 \%$ agree, $27 \%$, were impartial, $17 \%$ disagree and only $10 \%$ were sturdily disagree.

Table 9. Talent retention and performance of employees

\begin{tabular}{|c|c|c|c|c|c|c|c|c|c|c|}
\hline \multirow[t]{2}{*}{ Talent Retention } & \multicolumn{2}{|c|}{ Sturdily Agree } & \multicolumn{2}{|c|}{ Agree } & \multicolumn{2}{|c|}{ Impartial } & \multicolumn{2}{|c|}{ Disagree } & \multicolumn{2}{|c|}{ Sturdily Disagree } \\
\hline & $\mathbf{F}$ & $\%$ & $\mathbf{F}$ & $\%$ & $\mathbf{F}$ & $\%$ & $\mathbf{F}$ & $\%$ & $\mathbf{F}$ & $\%$ \\
\hline $\begin{array}{l}\text { Q 9. My organization has a mechanism to find talent within the } \\
\text { organization. }\end{array}$ & 24 & 15 & 54 & 35 & 45 & 29 & 24 & 15 & 9 & 6 \\
\hline $\begin{array}{l}\text { Q 10. My } \quad \text { organization evaluates and } \\
\text { communicatesJobperformance ofemployees. }\end{array}$ & 15 & 10 & 69 & 44 & 36 & 23 & 27 & 17 & 9 & 6 \\
\hline $\begin{array}{l}\text { Q 11. Performance appraisals have a positive impact on } \\
\text { employee's performance. }\end{array}$ & 36 & 23 & 63 & 40 & 15 & 10 & 27 & 17 & 15 & 10 \\
\hline $\begin{array}{l}\text { Q 12. My organization believes that all positions need talented } \\
\text { employees. }\end{array}$ & 21 & 13 & 51 & 33 & 42 & 27 & 27 & 17 & 15 & 10 \\
\hline
\end{tabular}

\subsection{Talent Management and Performance of Employees}

This portion pursued to conclude the opinions of the respondents on to what extents talent management affects the performance of employees. The finding are shown in the table 10. The participants of this questionnaire survey were asked to designatewhether my organization emphases on elevation and developments need of employees. The results shows that $15 \%$ are sturdilyagree, $35 \%$ agree, $23 \%$, were impartial, $19 \%$ disagree and only $8 \%$ were sturdily disagree.Respondents of the study were asked to indicate whether my organization has systematic succession plans. The results shows that $10 \%$ are sturdilyagree, $44 \%$ agree, $25 \%$, were impartial, $18 \%$ disagree and only $10 \%$ were sturdily disagree.On the question to respondent of the study were asked to indicate whether my organization has development programs that sturdily influence staff retention. The results shows that $10 \%$ are sturdilyagree, $37 \%$ agree, $25 \%$, were impartial, $13 \%$ disagree and only $15 \%$ were sturdily disagree.On the question to respondent of the study were asked to indicate whether training initiatives enhance employee performance. The results shows that $31 \%$ are sturdilyagree, $44 \%$ agree, $17 \%$, were impartial, $2 \%$ disagree and only $6 \%$ were sturdily disagree.

Table 10. Talent management and performance of employees

\begin{tabular}{|c|c|c|c|c|c|c|c|c|c|c|}
\hline \multirow[t]{2}{*}{ Talent Management } & \multicolumn{2}{|c|}{ Sturdily Agree } & \multicolumn{2}{|c|}{ Agree } & \multicolumn{2}{|c|}{ Impartial } & \multicolumn{2}{|c|}{ Disagree } & \multicolumn{2}{|c|}{ Sturdily Disagree } \\
\hline & $\mathbf{F}$ & $\%$ & $\mathbf{F}$ & $\%$ & $\mathbf{F}$ & $\%$ & $\mathbf{F}$ & $\%$ & $\mathbf{F}$ & $\%$ \\
\hline $\begin{array}{l}\text { Q13 My organization focuses on the promotion and } \\
\text { development need of employees. }\end{array}$ & 24 & 15 & 54 & 35 & 36 & 23 & 30 & 19 & 12 & 8 \\
\hline Q14 My organization has systematic succession plans. & 15 & 10 & 69 & 44 & 39 & 25 & 18 & 12 & 15 & 10 \\
\hline $\begin{array}{l}\text { Q15 My organization has development programs that strongly } \\
\text { influence staff retention. }\end{array}$ & 15 & 10 & 57 & 37 & 39 & 25 & 21 & 13 & 24 & 15 \\
\hline Q16 Training initiatives enhance employee performance. & 48 & 31 & 69 & 44 & 27 & 17 & 3 & 2 & 9 & 6 \\
\hline
\end{tabular}

\subsection{Performance of Employees}

This segment pursued to conclude the opinions of the respondent on to what extentstalent development affects 
the enactment of employee. The finding are shown in the table 11. The participants of this questionnaire survey were asked to designate whether career development affects the performance of employee. The results shows that $31 \%$ are sturdilyagree, $48 \%$ agree, $10 \%$, were impartial, $9 \%$ disagree and only $6 \%$ were sturdily disagree.Respondents of the study were asked to indicate whether Employee motivation through talent identification and succession planning enhances employee performance. The results shows that $31 \%$ are sturdilyagree, $50 \%$ agree, $8 \%$, were impartial, $6 \%$ disagree and only $6 \%$ were sturdily disagree.On the question to respondent of the study were asked to indicate whether performance appraisal system with feedback process enhances employee performance. The results shows that $27 \%$ are sturdilyagree, $42 \%$ agree, $17 \%$, were impartial, $4 \%$ disagree and only $10 \%$ were sturdily disagree.On the question to respondent of the study were asked to indicate whether fair and transparent talent acquisition policy \& process enhance employee performance. The results shows that $29 \%$ are sturdilyagree, $52 \%$ agree, $8 \%$, were impartial, $6 \%$ disagree and only $6 \%$ were sturdily disagree.

Table 11. Performance of employees

\begin{tabular}{|c|c|c|c|c|c|c|c|c|c|c|}
\hline \multirow[t]{2}{*}{ Performance of Employee } & \multicolumn{2}{|c|}{ Sturdily Agree } & \multicolumn{2}{|c|}{ Agree } & \multicolumn{2}{|c|}{ Impartial } & \multicolumn{2}{|c|}{ Disagree } & \multicolumn{2}{|c|}{ Sturdily Disagree } \\
\hline & $\mathbf{F}$ & $\%$ & $\mathbf{F}$ & $\%$ & $\mathbf{F}$ & $\%$ & $\mathbf{F}$ & $\%$ & $\mathbf{F}$ & $\%$ \\
\hline Q17 Career development enhances employee performance. & 48 & 31 & 75 & 48 & 15 & 10 & 9 & 6 & 9 & 6 \\
\hline $\begin{array}{l}\text { Q18 Employee motivation through talent identification and } \\
\text { succession planning enhances employee performance. }\end{array}$ & 48 & 31 & 78 & 50 & 12 & 8 & 9 & 6 & 9 & 6 \\
\hline $\begin{array}{l}\text { Q19 Performance appraisal system with feedback process } \\
\text { enhances employee performance. }\end{array}$ & 42 & 27 & 66 & 42 & 27 & 17 & 6 & 4 & 15 & 10 \\
\hline $\begin{array}{l}\text { Q20 Fair and transparent talent acquisition policy \& process } \\
\text { enhance employee performance. }\end{array}$ & 45 & 29 & 81 & 52 & 12 & 8 & 9 & 6 & 9 & 6 \\
\hline
\end{tabular}

\subsection{Correlation Analysis}

In statistics for measuring the linear correlation between variables like $\mathrm{X}$ and $\mathrm{Y}$, the Pearson correlation coefficient is used. The Pearson correlation coefficient is referred as Pearson's $r$ or bivariate correlation. According to Cauchy-Schwarz, the Pearson correlation coefficient is used. The Pearson correlation coefficient is referred as Pearson's r or bivariate correlation. According to Cauchy-Schwarz, during the state of inequality, it value varies between +1 to -1 . Where +1 indicates that there is positive linear correlation exist between values, while 0 indicates that there is no linear correlation, and -1indicates that there is total negative linear correlation. The correlation analyses showed in order to conclude either the existence of relationship between talent acquisition, retention, training and management, and employee performance. Following abbreviations are used: $\mathbf{P}$ for employee performance, TA for talent acquisition, TD for talent development, TR for talent retention and TM for talent management. The outcome of the studies shows that talent acquisition system and employee performance, $\mathrm{r}(0.670842)$, therefor, there is moderate positive correlation among talent acquisition systems and performance of theemployee. Employee's performance and talent retention has $r$ (0.72626). This shows there is a strong correlation between talent retention and employee performance. Talent development and employee performance is shown as, $r(0.737622)$, therefore, there is a strong correlation between training and development and employee performance. Talent management and employee performance is shown as, $r$ (0.72921), therefore, there is a strong correlation between talent management and employee performance.Furthermore, there is strong positive correlation between talent development, talent retention, talent management and talent acquisition. The relationship between talent acquisition and talent management is the strongest. This is illustrated in Table 12 . 
Table 12. Correlation analyses

\begin{tabular}{|c|c|c|c|c|c|}
\hline & P & TA & TD & TR & TM \\
\hline P & 1 & 0.670842 & 0.737622 & 0.72626 & 0.72921 \\
\hline TA & & 1 & 0.726932 & 0.832534 & 0.869096 \\
\hline TD & & & 1 & 0.794959 & 0.827399 \\
\hline TR & & & & 1 & 0.827399 \\
\hline TM & & & & & 1 \\
\hline
\end{tabular}

\section{Conclusions}

This research based surveytrying to conclude that component of talent management have positive influence on employeeperformance of public sector in UAE. It may also be concluded that public sector organizationsthat will design and implement different talent management policies will have higher employee performance. The study exposed that practices such as the strategiesrelated to employee progressionandgrowth,established career paths,retirement facilities and counselling programscontribute positively to employee performance.The point of this research base survey to highlight the effects of talent management strategies to enhance the performance of employees. The research questions conducted in this study was: To which extend do talent acquisition, talent development, and talent retention and talent management affect employee performance.The study uses a descriptive survey research design. Sample size of 156 respondents was selected by Stratified sampling technique. Anorganized close ended questionnaireswere usedfor collection ofinitial data. Which was used to analyze for both expressive, inferential statistics and presented using table and figures.

The study shows a substantial relationship between all four dimensions of talent management and employee's performance. Mostly respondents believe that systematic training, suitable work environment and mechanisms for training and development enhance employee's performance.The study revealed a moderatepositive relationship between talent acquisition strategy and employee's performancer [(0.670842)] while a strong positive relationship between talent development, retention and management and employee's performance $[\mathrm{r}$ $(0.737622), \mathrm{r}(0.72626)$ and $\mathrm{r}(0.72921)$ respectively].There is also strong positive correlation between talent development, talent retention, talent management and talent acquisition.

Most respondent believed that identification and preparation of potential employees for key role and well-articulated succession plans that enables employees to perform managerial roles enhances employee's performance.Many of respondents believed that proper appraisal evaluation, communication process, involvement of employees in appraisal process and constructive feedback enhance employee's performance. Most respondents believed that learning and development practices like learning need identification, coaching and in-house development programs improve their performance. We can conclude that talent management strategies will enhance employee performance in public sector organization in UAE.

\section{References}

Ahmed, H. K. (2016). The impact of Talent management on the competitive advantage in the organizations. UAE Proceedings of 37th ISERD International Conference, Abu Dhabi, UAE, 6th June 2016.

Altaee, H., Salih, A. A., \& AlWaeli, D. F. (2015). Competencies and Talent Management (2nd ed.). Rashad press Lebanon- Beirut.

Altaee, Y. H., \& Thabit, M. (2018). Basics of Talent Management in Business Organizations. Dar Al Manhajihia Publishing and Distributing.

Armstrong, M. (2009). Armstrong's handbook of Human Resources Management. Kogan Page, UK. Boudre.

Brewster, C., Sparrow, P., \& Vernon, G. (2007). International human resource management. London, UK.

Cappelli, P. (March 2008). Just-in-time talent how to develop a supply chain of people. Computerworld. p.34.

Chou, S. Y. (2012). Millennials in the workplace: A conceptual analysis of millennia's' leadership and followership styles. International Journal of Human Resource Studies, 2(2), 71-83. https://doi.org/10.5296/ijhrs.v2i2.1568

Dahham, Q., \& Walid, H. (n.d.). Talent Management as an introduction to Contemporary Human Resource management (1st ed.). Al Hamid Printing and Publishing Amman- Jordan. 
Echols, M. (2007). Winning the turnover war. Retrieved from www.talentmgt.com

Gardner, T. M. (2002). In the trenches at the talent wars: competitive interaction for scarce human resources. Human Resources management, Wiley periodicals, 41, 225-237. https://doi.org/10.1002/hrm.10033

Gomez-Mejia, L. R., Balkin, D. B., \& Robert, L. C. (2006). Managing human resources (4th ed.). Prentice Hall, USA.

Heinen, S. J., \& O'Neill, C. (2004). Managing Talent to maximize performance. Published online in Wiley interscience. https://doi.org/10.1002/ert.20018

Hejase, H. J. (2016). Talent Management Challenges: An Exploratory Assessment from Lebanon. International Journal of Business Management and Economic Research, 7(1), 504-520.

Hilal, M. G. (2011). Talent Management. Performance Development Center, Cairo Egypt.

https://goo.gl/forms/06hdFf8xBWsO2a8z1

https://goo.gl/forms/7SPIXtd8yVNXGABz2

Human Resource Management in the United Arab Emirates November. (2016). In book: Handbook of Human Resource Management in the Middle East Chapter: 7. Publisher: Cheltenham, UK: Edward Elgar Publishing Limited.

Kapoor, B. (2009). Impact of Globalization on Human Resource Management. Cal State University, p. 1- 8.

Kelley, S. (2004). Leadership development in China: A long way to go China Staff.

Koketso, L. P., \& Rust, A. B. (2012). Perceived challenges to talent management in the South African public service: An exploratory study of the City of Cape Town municipality. African Journal of Business Management, 6(6), 2221. https://doi.org/10.5897/AJBM11.2169

Lockwood, N. R. (2006). Talent management: Driver for organizational successes, research Quarterly. Society for Human Resource management.

London, M., Mone, E., \& Scott, J. (Winter, 2004). Performance management and assessment: methods for improved rater accuracy and employee goal. Human Resource, 43(4), 319-336. https://doi.org/10.5897/AJBM11.2169

Lyria, R. K. (2013). Effect of Talent Management on Organizational Performance in Companies Listed in Nairobi Securities Exchange in Kenya. Unpublished Master Thesis, Jomo Kenyatta University, Nairobi.

Mathis, R. L., \& Jackson, J. H. (2008). Human resource management. Mason, OH: Thomson South Western.

Mendez, \& Stander. (2011). Positive Organization. The role of leader Behavior in work engagement and Retention. South African Journal of Industrial Psychology, 1(37). https://doi.org/10.4102/sajip.v38i1.900

Meyer, J. P., \& Smith, C. A. (2001). HRM Practices and organizational commitment: Test of a mediation model. $\begin{array}{lllll}\text { Canadian Journal of Administrative } & \text { Sciences, } & \text { 14(4), } 331 .\end{array}$ https://doi.org/10.1111/j.1936-4490.2000.tb00231.x

Northuse, P. G. (2010). Leadership: Theory and practice (5th ed.). Thousand Oaks, CA: Sage Publications, Inc.

Ramstad, P. M. (2007). Beyond HR: The new Science of Human Capital. Boston, MA, Harvard Business Press.

Singh, A., \& Sharma, J. (2015). Strategies for talent management: a study of select organizations in the UAE. $\begin{array}{lllll}\text { International Journal of } & \text { Organizational }\end{array}$ https://doi.org/10.1108/IJOA-11-2014-08235.

Sunday, K. J. (2012). Talent management effect on organization performance. Journal of management research, 4(2). https://doi.org/10.5296/jmr.v4i2.937

Wambui, N. (2012). Talent Management Practices in Commercial State Corporations in Kenya. Unpublished Master Thesis, university of Nairobi.

Waxin, Lindsay, V. J., Belkhodja, O., \& Zhao, F. (2018). Workforce Localization in the UAE: Recruitment and Selection Challenges and Practices in Private and Public Organizations. The Journal of Developing Areas, 52(4), 99-113. https://doi.org/10.1353/jda.2018.0054 


\section{Appendix-A}

\section{SECTION A: Background Information}

1. What is your Gender?

Female [ ] Male []

2. What is your job/grade level?

Junior Management [ ] Middle Management [ ] Senior Management [ ]

3. How long have you worked for this organization?

Less than 2 years [ ] 3-5 years [ ] $\quad 6-8$ years [ ] 9 years and over [ ]

4. How do you rate your performance?

Excellent [ ] Very Good [ ] Good [ ] Room for improvement [ ] Not to my satisfaction [ ]

5. Do you think the HR department is relevant to this organization?

Yes []

No []

Note:

\begin{tabular}{ll}
\hline Strongly Agree & 5 \\
\hline Agree & 4 \\
\hline Neutral & 3 \\
\hline Disagree & 2 \\
\hline Strongly Disagree & 1 \\
\hline
\end{tabular}

\section{SECTION B:}

Q1 My organization has a fair and transparent talent acquisition policy \& process.

$\begin{array}{lllll}5 & 4 & 3 & 2 & 1\end{array}$

Q2 My organization knows the value of running the cycle of talent acquisition timely.

$\begin{array}{lllll}5 & 4 & 3 & 2 & 1\end{array}$

Q3 Talent acquisition process and timelines are shared with the candidates.

$\begin{array}{lllll}5 & 4 & 3 & 2 & 1\end{array}$

Q4 After acquiring talent the process of onboarding the employees is friendly and easy.

$\begin{array}{lllll}5 & 4 & 3 & 2 & 1\end{array}$

Q5 My organization facilitates employees to learn job related competencies.

$\begin{array}{lllll}5 & 4 & 3 & 2 & 1\end{array}$

Q6 My organization offers systematic trainings to employees.

$\begin{array}{lllll}5 & 4 & 3 & 2 & 1\end{array}$

Q7 My organization improves talent.

$\begin{array}{lllll}5 & 4 & 3 & 2 & 1\end{array}$

Q8 My organization implements staff development activities.

$\begin{array}{lllll}5 & 4 & 3 & 2 & 1\end{array}$

Q9 My organization has a mechanism to find talent within the organization.

$\begin{array}{lllll}5 & 4 & 3 & 2 & 1\end{array}$

Q10 My organization evaluates and communicates job performance of employees.

$\begin{array}{lllll}5 & 4 & 3 & 2 & 1\end{array}$


Q11 Performance appraisals have a positive impact on employee's performance.

$\begin{array}{lllll}5 & 4 & 3 & 2 & 1\end{array}$

Q12 My organization believes that all positions need talented employees.

$\begin{array}{lllll}5 & 4 & 3 & 2 & 1\end{array}$

Q13 My organization focuses on the promotion and development need of employees.

$\begin{array}{lllll}5 & 4 & 3 & 2 & 1\end{array}$

Q14 My organization has systematic succession plans.

$\begin{array}{lllll}5 & 4 & 3 & 2 & 1\end{array}$

Q15 My organization has development programs that strongly influence staff retention.

$\begin{array}{lllll}5 & 4 & 3 & 2 & 1\end{array}$

Q16 Training initiatives enhance employee performance.

$\begin{array}{lllll}5 & 4 & 3 & 2 & 1\end{array}$

Q17 Career development enhances employee performance.

$\begin{array}{lllll}5 & 4 & 3 & 2 & 1\end{array}$

Q18 Employee motivation through talent identification and succession planning enhances employee performance. $\begin{array}{lllll}5 & 4 & 3 & 2 & 1\end{array}$

Q19 Performance appraisal system with feedback process enhances employee performance. $\begin{array}{lllll}5 & 4 & 3 & 2 & 1\end{array}$

Q20 Fair and transparent talent acquisition policy \& process enhance employee performance.

$\begin{array}{lllll}5 & 4 & 3 & 2 & 1\end{array}$

\section{Copyrights}

Copyright for this article is retained by the author(s), with first publication rights granted to the journal.

This is an open-access article distributed under the terms and conditions of the Creative Commons Attribution license (http://creativecommons.org/licenses/by/4.0/). 